\title{
POTENTIAL USE OF WINTER GREEN MANURE SPECIES FOR NITROGEN RECYCLING BY 'NIAGARA ROSADA’ GRAPEVINES
}

\section{USO PONTENCIAL DE ESPÉCIES DE ADUBOS VERDES DE INVERNO PARA A RECICLAGEM DE NITROGÊNIO POR VIDEIRAS 'NIAGARA ROSADA’}

\author{
João R. Reis Júnior ${ }^{1}$, Renato V. Botelho ${ }^{1 *}$, Anderson R. Trevizam¹, Marcelo M. L. Müller ${ }^{1}$, José A. \\ Bendassolli ${ }^{2}$, Adamo D. Rombolà
}

\author{
${ }^{1}$ Centro Universidade Estadual do Centro-Oeste, Departamento de Agronomia. Campus Cedeteg, Rua Simeão Camargo Varella de Sá, 03, CEP \\ 85040-080, Guarapuava, Paraná, Brazil \\ ${ }^{2}$ Laboratório de Isótopos Estáveis, Centro de Energia Nuclear na Agricultura, USP, Av. Centenário, 303, CP96, Piracicaba, São Paulo, Brazil \\ ${ }^{3}$ Università di Bologna, Dipartimento di Scienze Agrarie Viale Fanin, 44, 40127, Bologna, Italy \\ *Corresponding author: Tel: 55-42-36298221, e-mail: rbotelho@unicentro.br
}

(Received 10.10.2013. Accepted 14.08.2014)

\section{SUMMARY}

Green manures have become an important option for recycling nutrients in organic cropping. However, its benefits are often not obtained in the short term. In this context, the study aimed to determine whether the use of cover crops during winter can contribute to $\mathrm{N}$ provision in the following spring, in the beginning of the growth of young grapevines. The winter green manure species white lupin (Lupinus albus), forage pea (Pisum arvense), common vetch (Vicia sativa), hairy vetch (Vicia villosa), triticale (Triticale hexaploide), oat (Avena sativa), ryegrass (Lollium multiflorum) and forage turnip (Brassica rapa) were grown until flowering in $4 \mathrm{~L}$ pots and fertilized with ammonium sulfate enriched at $10 \%$ with ${ }^{15} \mathrm{~N}$ atoms. In the following spring, grapevines cv. Niagara Rosada (Vitis labrusca) grafted on two different rootstocks (IAC-572 'Jales' and IAC 766 'Campinas') were planted in $14 \mathrm{~L}$ pots where it was superficially applied one of the five different sources of N. The green manure species employed as $\mathrm{N}$ source were forage pea (Pisum arvense), common vetch (Vicia sativa), hairy vetch (Vicia villosa) and oat (Avena sativa). The soil surface was covered with the dry matter from the green manure species (3g dry matter pot ${ }^{-1}$ ) or fertilized with ammonium sulfate enriched at $2 \%$ with ${ }^{15} \mathrm{~N}$ atoms. The results demonstrated that the oat plants showed the highest dry matter content (11.68 g pot $\left.{ }^{-1}\right)$. The species forage pea, hairy vetch and common vetch had the lowest $\mathrm{C} / \mathrm{N}$ ratios, with values of 16,16 and 18 , respectively. Hairy vetch was the most efficient (255.1 mg pot ${ }^{-1}$ ) for the accumulation of $\mathrm{N}$ and oat plants showed the highest $\mathrm{N}$ uptake from the mineral fertilizer. The $\mathrm{N}$ uptake and accumulation by the 'Niagara Rosada' grapevines varied according to N source and rootstock. Grapevines accumulated N in higher amounts from mineral fertilizer, followed by the $\mathrm{N}$ from leguminous species and then lower quantities from the oat plants. Grapevines grafted on the IAC-572 'Jales' rootstock accumulated higher amounts of $\mathrm{N}$ than those grafted on IAC-766 'Campinas', probably due its higher vigor and, consequently, better soil exploration by the roots. Despite of the rootstock, between the green manure species, the $\mathrm{N}$ from forage peas was the most recovered by the grapevines $\mathrm{cv}$. Niagara Rosada, attaining $30.8 \%$, while common vetch $23.1 \%$, hairy vetch $19.0 \%$, and oat only $5.2 \%$.

\section{RESUMO}

Os adubos verdes constituem uma importante opção na reciclagem de nutrientes em sistemas de produção orgânicos. No entanto, os seus benefícios normalmente não são obtidos num curto prazo. Neste contexto, este estudo teve como objetivo determinar se o uso de culturas de cobertura durante o inverno pode contribuir para o fornecimento de azoto na primavera seguinte, no início do desenvolvimento de videiras jovens. As espécies tremoço branco (Lupinus albus), ervilha forrageira (Pisum arvense), ervilhaca comum (Vicia sativa), ervilhaca peluda (Vicia villosa), triticale (Triticale hexaploide), aveia (Avena sativa), azevém (Lollium multiflorum) e nabo forrageiro (Brassica rapa) foram cultivadas até o florescimento em vasos de 4 litros e marcados isotopicamente, usando sulfato de amônio enriquecido com $10 \%$ de átomos de ${ }^{15} \mathrm{~N}$. Na primavera seguinte, videiras cv. Niagara Rosada (Vitis labrusca) enxertadas sobre dois diferentes porta-enxertos (IAC-572 'Jales' e IAC 766 'Campinas') foram plantadas em vasos de $14 \mathrm{~L}$ onde foi aplicado superficialmente, uma de cinco diferentes fontes de N. As espécies de adubos verdes utilizadas como fontes de $\mathrm{N}$ foram a ervilha forrageira (Pisum arvense), a ervilhaca comum (Vicia sativa), a ervilhaca peluda (Vicia villosa) e a aveia (Avena sativa). A superfície do solo foi coberta com o material seco das espécies de adubos verde (3 $\mathrm{g}$ matéria seca vaso ${ }^{-1}$ ) ou adubado com sulfato de amônio enriquecido a $2 \%$ com átomos de ${ }^{15} \mathrm{~N}$. Os resultados demostraram que as plantas de aveia branca apresentaram um maior teor de material seca (11.68 $\left.\mathrm{g} \mathrm{vaso}^{-1}\right)$. As espécies ervilha forrageira, ervilhaca peluda e ervilhaca comum apresentaram as menores relações C/N, com valores de 16, 16 e 18, respetivamente. A ervilhaca peluda foi a mais eficiente ( $255.1 \mathrm{mg}$ vaso $^{-1}$ ) para o acúmulo de $\mathrm{N}$ e a aveia branca apresentou a maior absorção de N como adubo mineral. A absorção e a acumulação de N pelas videiras 'Niagara Rosada’ variaram em função da fonte de N e do porta-enxerto. $\mathrm{O}$ fertilizante mineral originou a maior $\mathrm{N}$ acumulação nas videiras, seguido pelas espécies leguminosas e posteriormente pela aveia branca. Videiras enxertadas sobre o porta-enxerto IAC-572 'Jales' acumularam maiores quantidades de $\mathrm{N}$ do que aquelas enxertadas sobre $\mathrm{o}$ IAC-766 'Campinas’, possivelmente pelo seu maior vigor e, consequentemente, melhor exploração do solo pelas raízes. Independentemente do porta-enxerto, entre as espécies de adubos verdes, o $\mathrm{N}$ proveniente da ervilha forrageira foi o mais reaproveitado pelas videiras cv. Niagara Rosada, atingindo $30.8 \%$, enquanto que a ervilhaca comum $23.1 \%$, a ervilhaca peluda $19.0 \%$, e a aveia branca $5.2 \%$.

Key words: Vitis labrusca, mineral nutrition, soil management, isotope, organic production.

Palavras-chave: Vitis labrusca, nutrição mineral, manejo do solo, isótopo, produção orgânica

44

This is an Open Access article distributed under the terms of the Creative Commons Attribution License (http://creativecommons.org/licenses/by/4.0), which permits unrestricted use, distribution, and reproduction in any medium, provided the original work is properly cited. 


\section{INTRODUCTION}

Brazil is the $16^{\text {th }}$ producer of grapes in the world, achieving 1.34 million ton yearly, being almost half of this amount destined for wine and juice production (Mello, 2011). The Paraná State, at the Southern Brazilian Region, is traditionally a tablegrape producer (Vitis vinifera), including cv. Italia and their mutations: Benitaka, Rubi, Brasil. Nevertheless, in the last years, the production of American cultivars (Vitis labrusca) has been widely spread around the State. The production of the cultivars Isabella, Ives and Niagara has been destined mostly for wine and juice, produced in family farms, but also for fresh consumption.

The adequate $\mathrm{N}$ management is essential for grapevines maintenance, exerting an important role on its vegetative growth, yield, grape quality, must fermentation and wine excellence. According to Keller et al. (2001), high soil nitrogen expanded vine leaf area by stimulating lateral-shoot growth, increased leaf chlorophyll, photosynthesis, transpiration and stomatal conductance, and delayed leaf senescence. Brunetto et al. (2007) verified in vines cv. Riesling a significant increase in yield after nitrogen fertilization, due to the enhancement in cluster mass and in number of berries per cluster. Nevertheless, $\mathrm{N}$ fertilization must be managed carefully. Excessive nitrogen can reduce the formation of fertile buds (Keller and Koblet, 1995). According to Wade et al. (2004), a high level of $\mathrm{N}$ applied from bloom to the veraison delayed ripening in grapes 'Shiraz', and resulted in a lower berry anthocyanin concentration, while postharvest $\mathrm{N}$ application increased the proline:arginine ratio.

One of the practices for grapevines $\mathrm{N}$ supply is the use of green manures, an important strategy for nutrient recycling in agroecosystems (Faria et al., 2004; Fourie et al., 2006a,b; Fourie et al., 2007). In vineyards the sowing of green manure species has as the main objective, to carry out soil protection against erosion, shelter for beneficial insects, humidity and temperature maintenance and also the improvement of soil fertility.

Faria et al. (2004), in an experiment using crotalaria and jack beans in a vineyard cv. Italia, verified that the green manures increased the soil cation exchange capacity, the organic matter content and the exchangeable calcium at the $0-10 \mathrm{~cm}$ layer. Nevertheless, no effects were verified for yield and fruit quality attributes.

Grapevine yield, vigor, fruit quality and vineyard dynamics were studied in the Estremadura Region of Portugal with a Mediterranean oceanic bioclimate. A 3-year study was carried out in a 15-year-old 'Cabernet Sauvignon' non-irrigated vineyard. Compared to soil tillage, the two sward treatments (permanent resident vegetation, and permanent sown cover crop) showed a higher water use, primarily during the spring. In the third season of the experiment, compared to cultivation treatment, the two sward treatments showed a significant, favorable reduction in vine vegetative growth. The sward treatments did not affect grapevine yield or berry sugar accumulation compared to the control, but reduced must acidity and increased berry skin total phenols and anthocyanins (Monteiro and Lopes, 2007).

With the purpose to compare and quantify the plant efficiency in $\mathrm{N}$ recycling with green manure and traditional soil management and fertilizers, the use of a source with ${ }^{15} \mathrm{~N}$ labeled is a method that allows to get information very precise about soil nutrients dynamic (Ambrosano et al., 2003). The rate by which legume organic residues are mineralized to plantavailable forms of soil mineral $\mathrm{N}$ (nitrate and ammonium) depends on the chemical composition of the legumes, residue management, soil properties and crop rotation (Ladd et al. 1985; Fillery, 2001; Carranca et al., 2009). In annual cropping systems $<20-25 \%$ of the $\mathrm{N}$ in forage legume residues or green manures is commonly recovered in the short-term, although legume $\mathrm{N}$ can sometimes represent up to $30-33 \%$ of the $\mathrm{N}$ requirements of a following crop (Fillery, 2001; Crews and Peoples, 2005). However, much less information is available in systems with perennial cropping systems. Ovalle et al. (2010) carried out a trial in a 5-year-old vineyard cv. Cabernet Sauvignon at the Cauquenes, Chile, to estimate the relative contribution of legume and fertilizer $\mathrm{N}$ to the $\mathrm{N}$ nutrition of grapevines. The treatments were: control without cover crop (C); a legume mixture of early maturing cultivars of subterranean clover (Trifolium subterraneum L.) and burr medic (Medicago polymorpha L.) (EMC); or a legume mixture of late maturing cultivar of subterranean clover and balansa clover ( $T$. michelianum Savi) (LMC). ${ }^{15} \mathrm{~N}$-enriched fertilizer (10 atom $\%{ }^{15} \mathrm{~N}$ excess) was applied to the soil as two split applications of $20 \mathrm{~kg} \mathrm{~N} \mathrm{ha}^{-1}$, The amount of legume $\mathrm{N}$ estimated to be recovered by cover cropped vine plants (12-15 kg N ha ${ }^{-1}$ ), was similar to the calculated contribution from $40 \mathrm{~kg}$ of fertilizer- $\mathrm{N}$ applied to vines (11-12 kg ha-1). This amount of $\mathrm{N}$ represented $<10 \%$ of the amounts of $\mathrm{N}$ annually returned to the soil in above-ground legume material in the case of the cover cropping treatments, and was equivalent to a recovery of $27-30 \%$ of the $\mathrm{N}$ applied as fertilizer.

Which winter manure species are more efficient for nitrogen accumulation and how fast this nutrient is available for young grapevines in the immediately follow spring are important questions that remain unknown. The influence of the rootstock is also an important parameter for vine nutrition aspects that should be consider. All this information could guide the winegrower to reduce or eliminate the use of 
mineral fertilizers, diminishing costs and the environmental impacts.

In this context, this trial aimed to evaluate nitrogen uptake and accumulation in 'Niagara Rosada' grapevines grafted on two different rootstocks and submitted to different green manure winter species as soil cover using the ${ }^{15} \mathrm{~N}$ labeled method.

\section{MATERIAL AND METHODS}

This experiment was carried out from $26^{\text {th }}$ August 2010 to $24^{\text {th }}$ March 2011, in a plastic greenhouse located in Guarapuava, Paraná State, Brazil
(25 $23^{\prime} 36^{\prime \prime}$ S and $51^{\circ} 27^{\prime} 19^{\prime \prime} \mathrm{W}, 1.120 \mathrm{~m}$ a.s.l.). The local climate classification according to Köppen is Cfb (subtropical mesothermal humid) (Caviglione et al., 2000).

The soil used in this trial was taken from $20-40 \mathrm{~cm}$ layer in a brown Latosol. Their chemical characteristics are presented in Table I. The soil was sieved $(<4.0 \mathrm{~mm})$ and mixed to calcitic lime to attain the base saturation level of $70 \%$. The soil was incubated by 30 days, before use to fill the pots, for decrease of soil acidity with lime reaction.

TABLE I

Chemical characteristics from 20-40 cm soil layer in a brown Latosol before lime application (Guarapuava, Paraná, Brazil, 2010)

Características químicas do solo entre 20-40 cm de profundidade de um latossolo castanho antes da aplicação de calcário

\begin{tabular}{|c|c|c|c|c|c|c|c|}
\hline \multirow{2}{*}{$\begin{array}{l}\mathrm{pH} \\
\mathrm{CaCl}_{2}\end{array}$} & \multirow{2}{*}{$\begin{array}{l}\mathrm{OM} \\
\mathrm{g} \mathrm{dm}^{-3}\end{array}$} & \multirow{2}{*}{$\begin{array}{l}\mathrm{P} \\
\mathrm{mg} \mathrm{dm^{-3 }}\end{array}$} & $\mathrm{H}+\mathrm{Al}$ & $\mathrm{Al}^{+3}$ & $\mathrm{Ca}$ & $\mathrm{Mg}$ & \multirow[t]{2}{*}{$\mathrm{K}$} \\
\hline & & & \multicolumn{4}{|c|}{$\mathrm{cmol} \mathrm{dm}^{-3}$} & \\
\hline 5.20 & 20.10 & 0.65 & 3.97 & 0.00 & 0.99 & 0.90 & 0.18 \\
\hline BS & CEC & V & $\mathrm{Zn}$ & $\mathrm{Fe}$ & $\mathrm{C}$ & $\mathrm{Mn}$ & SAT. Al \\
\hline \multicolumn{2}{|c|}{---- $\mathrm{cmol} \mathrm{dm}^{-3}$} & $\%$ & \multicolumn{4}{|c|}{ - mg dm ${ }^{-3}$} & $\%$ \\
\hline 2.07 & 6.04 & 34.27 & 1.10 & 15.41 & 0.21 & 9.66 & 0.00 \\
\hline
\end{tabular}

Methodology: OM by humid digestion. P, K, Cu, Fe, Zn and Mn extracted with Mehlich-I solution; $\mathrm{pH}$ in $\mathrm{CaCl}_{2}$ 1:2.5 Ca, $\mathrm{Mg}$ and $\mathrm{Al}$ exchangeable with $\mathrm{KCl} 1 \mathrm{~mol} \mathrm{~L}^{-1}$ (Pavan and Chaves, 1998).

\section{Nitrogen recovery from mineral fertilizer by winter green manure species}

The experimental design was in randomized blocks, with eight treatments (green manures species), four replications and one-pot experimental plot. The following species were used: white lupin (Lupinus albus), forage pea (Pisum arvense), common vetch (Vicia sativa), hairy vetch (Vicia villosa), triticale (Triticale hexaploide), oat (Avena sativa), ryegrass (Lollium multiflorum) e forage turnip (Brassica rapa).

The sowing of green manure seeds was in the middle of the autumn in Brazilian conditions, in $13^{\text {th }}$ May 2010, considering the area surface of the pot $(0.036$ $\mathrm{m}^{2}$ ) and the references of each specie in field conditions (Aita et al., 2004). Ten days after seedlings emergence, it was realized the roughing, leaving five plants per pot for white lupin and forage turnip; seven plants per pot for common vetch, hairy vetch, oat and forage pea and; 15 plants per pot for triticale and ryegrass.

A solution containing $100 \mathrm{mg}$ of sulfate ammonium enriched in $10 \%$ in ${ }^{15} \mathrm{~N}$ atoms was applied in each pot at 15,30 and 45 days after seedlings emergence, totalizing $300 \mathrm{mg}$ of sulfate ammonium per pot (three split applications of $100 \mathrm{mg}$ ). At the thirtieth day, it was applied $70 \mathrm{mg}$ of $\mathrm{P}$ and $88 \mathrm{mg}$ of $\mathrm{K}$ by pot, using potassium phosphate in an aqueous solution. These amounts applied corresponded to $17.6 \mathrm{~kg} \mathrm{~N} \mathrm{ha}^{-1}, 19.4$ kg $\mathrm{P} \mathrm{ha}{ }^{-1}$ and $24.4 \mathrm{~kg} \mathrm{~K} \mathrm{ha}^{-1}$.
The pots were kept in a plastic greenhouse, under intermittent irrigation, and the plants were removed in the beginning of the flowering. Therefore, the plants were sampled 96 days after sowing for forage pea, 103 days for oat, 105 days for white lupin and forage turnip, 108 days for hairy vetch, 115 days for common vetch, 119 days for triticale and 139 days for ryegrass.

The plants were cut at soil level and then, the samples were washed in distilled water, dried at $65{ }^{\circ} \mathrm{C}$ until constant weight and kept in plastic containers to be used for mulching in the grapevines. Subsamples of $100 \mathrm{mg}$ (particles $<0.6 \mathrm{~mm}$ ) were taken for total C, $\mathrm{N}$ and ${ }^{15} \mathrm{~N}$ enrichment.

\section{Nitrogen recovery by 'Niagara Rosada' grapevines from mineral fertilizer and winter green manures}

Four green manure species were selected considering the results from the first part of the trial, considering those with higher dry matter production and $\mathrm{N}$ accumulation. The experimental design was in randomized blocks with a factorial scheme $2 \times 5$ (rootstocks $\mathrm{x} \mathrm{N}$ sources), totalizing 10 treatments, four replications and one-plant-plot. The rootstocks used were IAC-766 'Campinas' ('106-8 Mgt' x $V$. caribaea) and IAC-572 'Jales' (V. caribaea x '101-14 Mgt'). The selected green manure species employed as $\mathrm{N}$ source were as following: forage pea (Pisum arvense), common vetch (Vicia sativa), hairy vetch 
(Vicia villosa) and oat (Avena sativa). An additional treatment with mineral fertilizer was included.

In the end of the follow winter, the grafted grapevines were planted in $26^{\text {th }}$ August 2010, in $14 \mathrm{~L}$ pot (oneplant-pot), previously filled with soil (Table I). Fourty-five days later, in spring, the different green manure species were applied covering the soil in uniform amounts of $3 \mathrm{~g} \mathrm{DM} \mathrm{pot}^{-1}$. Based on the area surface of the pot, this amount represented about 492 $\mathrm{kg} \mathrm{DM} \mathrm{ha}{ }^{-1}$ in field conditions. The mineral fertilizer treatment was composed of ammonium sulfate at 300 mg $\mathrm{N}_{\text {pot }}{ }^{-1}$, labeled with $2 \%$ in excess of ${ }^{15} \mathrm{~N}$, split in three applications (100 mg $\mathrm{N} \mathrm{pot}^{-1}$, each application), each 30 days after planting the grapevines.

The grapevines were conducted into a plastic greenhouse and trained in a cordon-spur with intermittent irrigation. At the end of the summer, in $24^{\text {th }}$ march 2011 (210 days after planting), the plants were completed removed from the soil. Then, the roots were washed in running water for complete elimination of the soil particles. The whole-plant samples (roots, stem and canes) were dried at $65^{\circ} \mathrm{C}$ in a forced-air drying oven. After 5 days, the samples were weighted and grinded in a Wiley mill.

\section{Plant analysis and isotopic calculations}

The plant samples (green manure and grapevines) were analyzed in relation to ${ }^{15} \mathrm{~N}$ enrichment (\% atoms) and total $\mathrm{N}$ in a mass spectrophotometer (IRMS), interfaced with an elementary stream analyzer, according to the methodology described by Barrie and Prosser (1996). From the results obtained, it was calculated the $\mathrm{N}$ use efficiency (\%), considering the amount and the enrichment (\% atoms of ${ }^{15} \mathrm{~N}$ in excess) of the $\mathrm{N}$ source applied, green manure ${ }^{15} \mathrm{~N}$ labeled, discounted the natural abundance of stable isotope ${ }^{15} \mathrm{~N}$, that is $0,366 \%$. The C contents from green manures were determined by dry combustion in a LECO equipment.

The following variables were estimated: dry matter production (DM), $\mathrm{N}$ content $(\mathrm{N}), \mathrm{N}$ accumulation (NA), $\mathrm{N}$ percentage recovery in plants from the $\mathrm{N}$ source (NPNS), Total $\mathrm{N}$ in the plant coming from each $\mathrm{N}$ source (NANS) e $\mathrm{N}$ use efficiency (\%), according to each $\mathrm{N}$ source (NUNS), according to the following equations:

a) Nitrogen accumulation

\section{$N A=N \times D M$}

Where: $N A=\mathrm{N}$ accumulation $\left(\mathrm{mg} \mathrm{pot}^{-1}\right) ; N=$ nitrogen content $\left(\mathrm{g} \mathrm{kg}^{-1}\right)$, and $D M=\operatorname{dry}$ matter $\left(\mathrm{g} \mathrm{pot}^{-1}\right)$.

b) $\mathrm{N}$ percentage recovery in plants from the $\mathrm{N}$ source (NPNS)

$$
N P N S=\frac{a-c}{b-c} \times 100
$$

Where: $a=$ abundance of ${ }^{15} \mathrm{~N}$ (\% atoms) in plant; $b=$ abundance of ${ }^{15} \mathrm{~N}$ (\% atoms) in $\mathrm{N}$ source, and $c=$ natural abundance of ${ }^{15} \mathrm{~N}(0,366 \%$ atoms $)$ in soil.

c) Total $\mathrm{N}\left(\mathrm{mg} \mathrm{pot}^{-1}\right)$ in the plant coming from each $\mathrm{N}$ source (NANS)

$$
N A N S=\frac{N P N S}{100} \times A N
$$

Where: $N P N S=\mathrm{N}$ percentage recovery in plants from the $\mathrm{N}$ source, and $N A=\mathrm{N}$ accumulated $\left(\mathrm{mg} \mathrm{pot}^{-1}\right)$.

d) $\mathrm{N}$ use efficiency (\%), according to each $\mathrm{N}$ source (NUNS)

$$
N U N S=\frac{N A N S}{N A A N S} \times 100
$$

Where: NANS = total $\mathrm{N}$ in the plant $\left(\mathrm{mg} \mathrm{pot}^{-1}\right)$ coming from each $\mathrm{N}$ source, and NAANS = Total $\mathrm{N}\left(\mathrm{mg} \mathrm{pot}^{-1}\right)$ in the $\mathrm{N}$ source.

The results were submitted to analysis of variance and when significant, the means were compared using the Tukey test at 5\%, using the SISVAR statistical program (Ferreira, 2011).

\section{RESULTS AND DISCUSSION}

\section{Nitrogen recovery from mineral fertilizer by winter green manures}

One of the main factors for the evaluation of a green manure for use as soil cover is its biomass production. The highest fresh weight was verified for hairy vetch, followed by oat, forage pea and common vetch. The lowest value was observed for triticale that did not differ from ryegrass and forage turnip. In relation to dry matter content, the highest value was verified for oat, followed by hairy vetch, forage pea and common vetch, that didn't show differences among themselves. The lowest dry matter was noticed for forage turnip followed by triticale, ryegrass and white lupin (Table II).

Green manure with high biomass production can increase the $\mathrm{N}$ level in soil and, in many cases, replace partially or completely the mineral nitrogen fertilizing for the subsequent crop (Carvalho and Amabile, 2006). The green manure can also increase organic matter content in soil, and cation exchange capacity (CEC), as reported by Chaves et al. (1997) and Chaves (2000) sowing lead tree (Leucena leucocephala), peanut (Arachis hypogaea), velvet bean (Stizolobium pruriens) and rattlepod (Crotalaria mucronata), on the interow of coffee threes.

Studies about $\mathrm{N}$ dynamic with green manure can be impaired due to the low variation in the isotopic relation in plants. In this research, the major part of the green manure species attained values higher than $2 \%$, as recommended by Ambrosano et al. (1997) to obtain reliable results for this scope of study. Ambrosano et al. (2003) studying the $\mathrm{N}$ dynamics 
using Crotalaria juncea labeled with ${ }^{15} \mathrm{~N}$, reached a dry matter with $2.412 \%$ in atoms of ${ }^{15} \mathrm{~N}$. Brunetto et al. (2014) in a trial with rye plants (Secale cereale) grown in pots and treated in soil with a urea solution, enriched with $5 \%{ }^{15} \mathrm{~N}$ excess, a dry matter with $2.37 \%$ in atoms of ${ }^{15} \mathrm{~N}$. In this trial, the exception was the white lupin with a lower value of $1.84 \%$, but considering the natural abundance of $0.336 \%$ already discounted, this specie reached the minimum necessary for this purpose, i.e. 2.176\% (Table II).

TABLE II

Fresh weight, dry matter production and percentage, excess of ${ }^{15} \mathrm{~N}$ atoms and $\mathrm{C} / \mathrm{N}$ ratios of different green manure species (Guarapuava, Paraná,

Brazil, 2010)

Peso verde, produção e percentagem de matéria seca, excesso de átomos de ${ }^{15} \mathrm{~N}$ e relação $\mathrm{C} / \mathrm{N}$ de diferentes espécies de adubos verdes

\begin{tabular}{|c|c|c|c|c|c|}
\hline \multirow{2}{*}{ green manure } & \multirow{2}{*}{$\begin{array}{c}\text { fresh weight } \\
\text { g vase }^{-1}\end{array}$} & \multicolumn{2}{|c|}{ dry matter } & \multirow{2}{*}{$\begin{array}{l}\text { excess } \\
{ }^{15} \mathrm{~N} \%\end{array}$} & \multirow{2}{*}{$\mathrm{C} / \mathrm{N}$} \\
\hline & & $\mathrm{g}_{\text {vase }} \mathrm{e}^{-1}$ & $\%$ & & \\
\hline Oat & $38.2 \mathrm{~b}$ & $11.7 \mathrm{a}$ & 30.6 & 8.16 & 32 \\
\hline Ryegrass & $13.3 \mathrm{e}$ & $5.0 \mathrm{~cd}$ & 37.4 & 5.51 & 38 \\
\hline Forage pea & $32.9 \mathrm{bc}$ & $7.4 \mathrm{~b}$ & 22.4 & 2.66 & 16 \\
\hline common vetch & $27.4 \mathrm{bcd}$ & $7.1 \mathrm{bc}$ & 25.8 & 3.08 & 18 \\
\hline Hairy vetch & $52.4 \mathrm{a}$ & $8.4 \mathrm{~b}$ & 16.0 & 2.25 & 16 \\
\hline Forage turnip & $15.0 \mathrm{e}$ & $2.2 \mathrm{e}$ & 14.9 & 5.88 & 37 \\
\hline Triticale & $18.8 \mathrm{de}$ & $4.8 \mathrm{~d}$ & 25.4 & 8.91 & 50 \\
\hline White lupin & 22.0 cde & $5.0 \mathrm{~cd}$ & 22.8 & 1.84 & 27 \\
\hline LSD & 12.4 & 2.27 & & & \\
\hline CV (\%) & 19.9 & 15.0 & & & \\
\hline
\end{tabular}

Means followed by the same letter in the same column did not differ by Tukey test $(\mathrm{p} \leq 0.05)$.

The addition of manure green in soil with high $\mathrm{C} / \mathrm{N}$ ratio promotes the competition for $\mathrm{N}$ available between microorganisms and plants; therefore, such parameter is important to take into account when considering the purpose of recycling nitrogen. In this study, forage pea, hairy vetch and common vetch showed $\mathrm{C} / \mathrm{N}$ ratios lower than 25 . On the other hand, white lupin, oat, ryegrass, forage turnip and triticale showed relation $\mathrm{C} / \mathrm{N}$ higher than 25 , which can cause a decrease in $\mathrm{N}$ availability for the successive crop (Table II). Many studies (Amado et al., 2002; Muraoka et al., 2002; Silva et al., 2008) showed that plant residues with $\mathrm{C} / \mathrm{N}$ ratio higher than 25/1 favors the temporary $\mathrm{N}$ immobilization from soil solution by the microorganisms. On the other hand, residues with $\mathrm{C} / \mathrm{N}$ ratio lower that $25 / 1$ accelerates mineralization and availability of $\mathrm{N}$ and other nutrients present in biomass

Doneda (2010) verified the following $\mathrm{C} / \mathrm{N}$ ratios for the different green manure species: black oat with $27 / 1$; forage turnip with $16.7 / 1$; forage pea with 13.7/1; and common vetch with $11.7 / 1$. The same author verified that the $\mathrm{C}$ content in plant tissue did not show significant differences, and the variations in $\mathrm{C} / \mathrm{N}$ proportions are due to differences between species in fixing or uptake $\mathrm{N}$ from atmosphere and soil, respectively.

Additionally, the high $\mathrm{C} / \mathrm{N}$ ratio can affect the rate of decomposition of crop residues, providing a more stable soil protection and a better synchronicity between $\mathrm{N}$ supply and demand from successive crops. Nevertheless, according to Weber et al. (2005), for hairy vetch, for example, with a percentage of $\mathrm{N}$ fixation of $67 \%$ and low $\mathrm{C} / \mathrm{N}$ ration, the decomposition rate was very high, and the $\mathrm{N}$ could not be more available for the next crop due to losses by ammonia emission into the atmosphere or nitrate leaching from soil to water (Cameron et al., 2013).

The $\mathrm{N}$ content was diverse between the green manure species, ranging from 5.7 to $30.5 \mathrm{~g} \mathrm{~kg}^{-1}$ (variation of $435 \%$ ) (Table III). The leguminous hairy vetch, common vetch and forage pea presented the highest $\mathrm{N}$ content, followed by white lupin and forage turnip, and then by the graminoids oat and ryegrass. Seyr (2011) verified $\mathrm{N}$ content in black oat and hairy vetch of 11.09 and $21.15 \mathrm{~g} \mathrm{~kg}^{-1}$, respectively, lower than values verified in this trial; while for forage turnip and white lupin the amounts found were 12.12 and $17.26 \mathrm{~g} \mathrm{~kg}^{-1}$, respectively, very similar to our results. On the other hand, Brunetto et al. (2014) reported $\mathrm{N}$ content of $41 \mathrm{~g} \mathrm{~kg}^{-1}$ in rye plants grown in pots.

In relation to the $\mathrm{N}$ accumulation by green manure species, the highest values were attained by the hairy vetch $\left(65.7 \mathrm{~kg} \mathrm{ha}^{-1}\right)$, common vetch $\left(50.9 \mathrm{~kg} \mathrm{ha}^{-1}\right)$, forage pea $\left(42.6 \mathrm{~kg} \mathrm{ha}^{-1}\right)$, and oat $\left(30.4 \mathrm{~kg} \mathrm{ha}^{-1}\right)$, while the other species showed $\mathrm{N}$ accumulation lower than $100 \mathrm{mg} \operatorname{pot}^{-1}\left(<27.7 \mathrm{~kg} \mathrm{ha}^{-1}\right)$ (Table III). For the $\mathrm{N}$ recovery coming the $\mathrm{N}$ source (NPNS), the highest values were found in the graminoids and in the forage turnip. In relation to the total $\mathrm{N}$ in the plant coming 
from $\mathrm{N}$ source (NANS), the oat was the species with the highest value followed by the common vetch, hairy vetch and triticale, and the lowest value was found in white lupin (Table III).

TABLE III

$\mathrm{N}$ content $(\mathrm{N}), \mathrm{N}$ accumulation (NA), $\mathrm{N}$ recovery coming from $\mathrm{N}$ source (NPNS), total $\mathrm{N}$ in the plant coming from $\mathrm{N}$ source (NANS) and $\mathrm{N}$ use efficiency (\%) according to the N source (NUNS) from different winter green manure species (Guarapuava-PR, Brazil, 2010). Conteúdo de $N(N)$, $N$ acumulado (NA), $N$ recuperado oriundo da fonte de $N$ (NANS) e Eficiência (\%) do uso do $N$ de acordo com a fonte de $N$ (NUNS) de diferentes espécies de adubos verdes de inverno (Guarapuava-PR, Brasil, 2010).

\begin{tabular}{|c|c|c|c|c|c|}
\hline \multirow{2}{*}{ green manure } & $\mathrm{N}$ & $\mathrm{NA}$ & $\mathrm{NPNS}^{(1)}$ & $\mathrm{NANS}^{(2)}$ & $\mathrm{NUNS}^{(3)}$ \\
\hline & $\mathrm{g} \mathrm{kg}^{-1}$ & $\mathrm{mg} \operatorname{pot}^{-1(4)}$ & $\%$ & $\mathrm{mg} \operatorname{pot}^{-1(4)}$ & $\%$ \\
\hline Oat & $9.3 \mathrm{e}$ & $109.3 \mathrm{c}$ & $39.7 \mathrm{~b}$ & $43.4 \mathrm{a}$ & $72.4 \mathrm{a}$ \\
\hline Ryegrass & $5.7 \mathrm{f}$ & $28.2 \mathrm{e}$ & $26.2 \mathrm{~d}$ & $7.4 \mathrm{c}$ & $12.3 \mathrm{e}$ \\
\hline Forage pea & $20.8 c$ & $153.7 \mathrm{~b}$ & $11.7 \mathrm{f}$ & $17.9 \mathrm{~b}$ & $29.9 \mathrm{~cd}$ \\
\hline Common vetch & $25.9 \mathrm{~b}$ & $183.4 \mathrm{~b}$ & $13.8 \mathrm{e}$ & $25.4 \mathrm{~b}$ & $42.4 \mathrm{~b}$ \\
\hline Hairy vetch & $30.5 \mathrm{a}$ & $255.1 \mathrm{a}$ & $9.6 \mathrm{~g}$ & $24.5 \mathrm{~b}$ & $40.9 \mathrm{bc}$ \\
\hline Forage turnip & $11.5 \mathrm{~d}$ & $25.4 \mathrm{e}$ & $28.1 \mathrm{c}$ & $7.1 \mathrm{c}$ & $11.9 \mathrm{e}$ \\
\hline Triticale & $11.2 \mathrm{de}$ & $53.5 \mathrm{de}$ & $43.5 \mathrm{a}$ & $23.3 \mathrm{~b}$ & $38.8 \mathrm{bc}$ \\
\hline White lupin & $17.2 \mathrm{~d}$ & $86.2 \mathrm{~cd}$ & $7.5 \mathrm{~h}$ & $6.4 \mathrm{c}$ & $10.8 \mathrm{e}$ \\
\hline LSD & 2.02 & 40.65 & 1.06 & 7.66 & 1.76 \\
\hline $\mathrm{CV}(\%)$ & 5.2 & 15.5 & 2.0 & 1.8 & 2.0 \\
\hline
\end{tabular}

${ }^{1} \mathrm{~N}$ recovery coming from mineral fertilizer; ${ }^{2}$ total $\mathrm{N}$ in the plant coming from mineral fertilizer; ${ }^{3} \mathrm{~N}$ use efficiency $(\%)$ according to the mineral fertilizer; ${ }^{4}$ surface area $=0.036 \mathrm{~m}^{2}$. Means followed by the same letter in the same column did not differ by Tukey test $(\mathrm{p} \leq 0.05)$.

The $\mathrm{N}$ use efficiency of $\mathrm{N}$ source (NUNS) was variable between green manure species (10.8 to $72.5 \%$ ), showing significant differences between all treatments. The highest NUNS were found in oat, followed by common vetch, hairy vetch, triticale, forage pea, ryegrass, forage turnip and white lupin (Table III).

According to Fiorin (1999), some winter green manure species such as vetch, white lupin and forage turnip can provide amounts of $\mathrm{N}$ fixed or recycled of 148, 129 and $138 \mathrm{~kg} \mathrm{ha}^{-1}$, respectively. Doneda (2010) verified in average $\mathrm{N}$ accumulation in biomass by forage turnip and forage pea of approximately 190 $\mathrm{kg} \mathrm{ha}^{-1}$ and; $137 \mathrm{~kg} \mathrm{ha}^{-1}$ for black oat and rye. These authors also reported that the high $\mathrm{N}$ accumulation by these green manure species is due to the fixation of $\mathrm{N}$ from atmosphere by symbiosis with rhizobia and/or for their elevated capacity of $\mathrm{N}$ recycling from the soil with high organic matter content.

In this research, oat, ryegrass, forage turnip and triticale presented high capacity of $\mathrm{N}$ uptake from soil solution, but also showed the highest $\mathrm{C} / \mathrm{N}$ ratios. These green manure species probably provided a slower mineralization, but favors a longer maintenance of organic matter in soil. On the other hand, a $\mathrm{N}$ source with a faster nutrient availability, could be provide by using the species forage pea, common vetch and hairy vetch, once they present a low $\mathrm{C} / \mathrm{N}$ relation, high biomass production and $\mathrm{N}$ accumulation.

Between the green manure species studied; oat, forage pea, common vetch and hairy vetch showed the highest dry matter production and $\mathrm{N}$ accumulation. Legumes showed a low $\mathrm{C} / \mathrm{N}$ ratio $(<20)$. Therefore, except oat, the other plant species sowed in the winter, apparently showed the best potential for providing $\mathrm{N}$ to the young grapevines in the following spring.

\section{Nitrogen recovery by 'Niagara Rosada' grapevines from mineral fertilizer and winter green manures}

In relation to the dry matter production of grapevines 'Niagara Rosada', there was no interaction between factors, or effect of the nitrogen source. Independently of the $\mathrm{N}$ source, grapevines 'Niagara Rosada' grafted on IAC-572 'Jales' rootstock showed higher dry matter production than those grafted on IAC-766 'Campinas' (Table IV). In relation to total N accumulation by 'Niagara Rosada' grapevines, there was no interaction between factors. Independently of the $\mathrm{N}$ source, the grapevines grafted on IAC-572 'Jales' rootstock attained the maximum nitrogen accumulation. Between the $\mathrm{N}$ sources, mineral fertilizer had the highest $\mathrm{N}$ accumulation in grapevines, followed by the leguminous species. The lowest $\mathrm{N}$ accumulation in grapevines was verified for the oat cover treatment that did not differ from hairy vetch (Table IV). 
TABLE IV

Dry matter production, $\mathrm{N}$ accumulation (NA), total $\mathrm{N}$ in the plant coming from $\mathrm{N}$ source (NANS), $\mathrm{N}$ use efficiency (\%) according to each $\mathrm{N}$ source (NUNS) from grapevines 'Niagara Rosada' in function of rootstock and N source (Guarapuava, Paraná, Brazil, 2011).

Produção de matéria seca, $N$ acumulado (NA), $N$ total na planta oriunda de cada fonte de $N$ (NANS), Eficiência do uso de $N$ de acordo com a fonte de $N$ (NUNS) de videiras 'Niagara Rosada' em função do porta-enxerto e da fonte de $N$.

\begin{tabular}{|c|c|c|c|c|c|c|}
\hline \multicolumn{7}{|c|}{ dry matter (g) } \\
\hline Rootstock & m. fertilizer & common vetch & hairy vetch & f. pea & oat & mean \\
\hline IAC-766 & 43.2 & 41.2 & 31.9 & 34.6 & 30.2 & $36.2 \mathrm{~b}$ \\
\hline IAC -572 & 41.5 & 41.9 & 46.6 & 43.1 & 37.6 & $42.2 \mathrm{a}$ \\
\hline Mean & 42.3 & 41.6 & 39.3 & 38.9 & 33.9 & \\
\hline \multicolumn{7}{|c|}{$\mathrm{N}$ accumulated $\left(\mathrm{mg} \mathrm{pot}^{-1}\right)$} \\
\hline Rootstock & m. fertilizer & common vetch & hairy vetch & f. pea & oat & mean \\
\hline IAC-766 & 416.7 & 265.4 & 342.4 & 291.6 & 207.8 & $281.2 \mathrm{~b}$ \\
\hline IAC -572 & 444.6 & 383.1 & 342.4 & 365.6 & 313.9 & $369.9 \mathrm{a}$ \\
\hline Mean & $430.6 \mathrm{a}$ & $324.3 \mathrm{~b}$ & $283.4 \mathrm{bc}$ & $328.6 \mathrm{~b}$ & $260.8 c$ & \\
\hline \multicolumn{7}{|c|}{ NANS $\left(\mathrm{mg} \mathrm{pot}^{-1}\right)$} \\
\hline Roostock & $\mathrm{N}$ mineral & c. vetch & h. vetch & f. pea & oat & Mean \\
\hline IAC-766 & 115.4 & 15.7 & 16.3 & 16.6 & 3.1 & $33.4 \mathrm{~b}$ \\
\hline IAC -572 & 118.5 & 20.1 & 18.3 & 22.1 & 4.4 & $36.7 \mathrm{a}$ \\
\hline Mean & $116.9 \mathrm{a}$ & $17.9 \mathrm{~b}$ & $17.3 \mathrm{~b}$ & $19.3 \mathrm{~b}$ & $3.7 \mathrm{c}$ & \\
\hline \multicolumn{7}{|c|}{ NUNS (\%) } \\
\hline Rootstock & m. fertilizer & common vetch & hairy vetch & f. pea & oat & mean \\
\hline IAC-766 & 38.5 & 20.2 & 17.9 & 26.5 & 4.3 & $21.5 \mathrm{~b}$ \\
\hline IAC -572 & 39.5 & 25.9 & 20.1 & 35.2 & 6.1 & $25.4 \mathrm{a}$ \\
\hline Mean & $39.0 \mathrm{a}$ & $23.1 \mathrm{c}$ & $19.0 \mathrm{~d}$ & $30.8 \mathrm{~b}$ & $5.2 \mathrm{e}$ & \\
\hline
\end{tabular}

Means followed by the same letter do not differ by the Tukey test $(\alpha \leq 0.05)$.

For the total $\mathrm{N}$ in the grapevine coming from each $\mathrm{N}$ source (NANS), there was no interaction. Independently of the rootstock, the grapevines treated with mineral fertilizer, attained the highest total $\mathrm{N}$, the leguminous reached intermediary values and the lowest amount was verified for the oat cover. In relation to the rootstocks, the IAC-572 'Jales' showed the highest total $\mathrm{N}$ in average (Table IV).

For $\mathrm{N}$ use efficiency (\%) according to each $\mathrm{N}$ source (NUNS), there was no interaction between factors. Independently of the rootstock, grapevines treated with mineral fertilizer showed the highest $\mathrm{N}$ use efficiency (39\%), the leguminous species presented intermediary results $(35.2-20.1 \%)$ and, the oat the lowest value $(5.2 \%)$. Between the cover species, the maximum recover was verified for forage pea $(30.8 \%)$ that was only $21.0 \%$ lower than the mineral fertilizer, considered, therefore, an efficient species for $\mathrm{N}$ recycling (Table IV).

The differences between leguminous species are related to inherent factors, such as lignin content and its relation to $\mathrm{N}$, determining a variable level of mineralization by the microorganisms and, consequently, its availability for grapevine plants. Independently of $\mathrm{N}$ source, grapevines 'Niagara Rosada' grafted on IAC-572 'Jales' rootstock showed $\mathrm{N}$ use efficiency $18.1 \%$ higher than IAC-766 'Campinas', probably due to its greater volume and/or length of roots.

Syvertsen and Smith (1996) verified in four-year-old Redblush grapefruit (Citrus paradisi Macf.) trees, $\mathrm{N}$ utilization ranging from 61 to $68 \%$ using only mineral fertilizer (applied in an average of $558 \mathrm{~g} \mathrm{~N} /$ tree per year). These percentages varied according to rootstock and amount of mineral fertilizer applied on the soil, in a five year trial. On the other hand, Brunetto et al. (2006), in an experiment with 'Chardonnay' grapevines in field conditions, verified low rates of $\mathrm{N}$ utilization ranging from 5.78 to $3.42 \%$, derived from annual ryegrass and white clover covers, respectively. Brunetto et al. (2014) using also the ${ }^{15} \mathrm{~N}$ isotopes labeling method, reported that The $\mathrm{N}$ derived from the rye litter added to the soil surface $(82 \mathrm{~kg} \mathrm{~N}$ $\mathrm{ha}^{-1}$ ) was mostly accumulated in the annual and perennial organs of the 'Niagara Rosada' grape at a similar percentage most of the $\mathrm{N}$ contained in 
'Niagara Rosada' grape organs was derived from different $\mathrm{N}$ sources rather than rye litter. Thus, the $\mathrm{N}$ derived from rye litter apparently contributed little to 'Niagara Rosada' grape nutrition in the short time period.

The results found in this research proved that the winter green manure plants, after mineralization, could lead to a reduction in the use of mineral fertilizers, aiming $\mathrm{N}$ supply for the young grapevines in the following spring (Almeida, 2007). According to Calegari (2010), the oat dry matter production could attain in average 3,5 $\mathrm{t} \mathrm{ha}^{-1}$ year $^{-1}$, the forage pea 4,2 $\mathrm{t}$ ha $^{-1}$ year $^{-1}$, common vetch $3,75 \mathrm{t} \mathrm{ha}^{-1}$ year $^{-1}$ and hairy vetch 4,5 $\mathrm{t} \mathrm{ha}^{-1}$ year $^{-1}$. In such conditions, and according to the results obtained in this research, these dry matter productions could recycle to the soil 32.6, 87.4, 97.0 and $137.3 \mathrm{~kg} \mathrm{~N} \mathrm{ha}^{-1}$, respectively.

Furthermore, the most part of $\mathrm{N}$ from green manure could stay in soil as organic matter that is beneficial to maintain soil properties. According to Amado et al. (2002), less than $50 \%$ of $\mathrm{N}$ incorporated to soil in organic form is transformed in inorganic, and the other part remains associated to microbial mass from the soil and could be available in the medium term.

\section{CONCLUSIONS}

The sowing of winter cover plants could lead to a reduction in the use of mineral fertilizers, aiming $\mathrm{N}$ supply for grapevines 'Niagara Rosada' (Vitis labrusca) in the following spring. Between the green manure species studied, the maximum recover was verified for forage pea (30.8\%) that was only 27.0 lesser than the mineral fertilizer. forage pea, hairy vetch and common vetch showed $\mathrm{C} / \mathrm{N}$ ratios lower than 25:1, that could improve $\mathrm{N}$ mineralization and availability for the grapevine subsequently planted.

The rootstock also has an important influence in $\mathrm{N}$ recover. Independently of $\mathrm{N}$ source, the IAC-572 'Jales' rootstock showed $\mathrm{N}$ utilization 18.1\% higher than IAC-766 'Campinas', probably due to its greater root volume and or/ length.

\section{REFERENCES}

Aita C., Giacomini S.J., Hübner A.P., Chiapinotto I.C., Fries M.R., 2004. Consorciação de plantas de cobertura antecedendo o milho em plantio direto. I - dinâmica do nitrogênio no solo. R. Bras. Ci. Solo, 28, 739-749.

Almeida M.M.T.B., 2007. Fertilizantes de leguminosas: Tecnologia inovadora de adubação verde para provisão de nitrogênio em sistemas orgânicos de produção. 96 p. Dissertação de mestrado, Universidade Federal Rural do Rio de Janeiro. Seropédica-RJ.

Amado T.J.C., Milniczuk J., Aita C., 2002. Recomendação de adubação nitrogenada para o milho no RS e SC adaptada ao uso de culturas de cobertura do solo, sob sistema plantio direto. R. Bras. Ci. Solo, 26, 241-248.

Ambrosano E.J., Trivelin P.C.O., Cantarella H., Rossetto R., Muraoka T., Bendassolli J.A., Ambrosano G.M.B., Tamiso L.G.,
Vieira F.C., Prada Neto I., 2003. Nitrogen-15 labeling of Crotalaria juncea green manure. Sci. Agric., 60, 181-184.

Ambrosano E.J., Muraoka, T., Trivelin P.C.O., 1997. Técnica para marcação dos adubos verdes crotalária júncea e mucuna-preta com ${ }^{15} \mathrm{~N}$ para estudos da dinâmica do nitrogênio. Bragantia, 56, 219224.

Barrie A., Prosser S.J., 1996. Automated analysis of light-element stable isotope ratio mass spectrometry. In: Mass spectrometry of soils. 1-46. Boutton T.W., Yamasaki, S. (ed.), Marcel Dekker, New York.

Brunetto G., Ceretta C.A., Kaminski J., Melo G.W.B., Lourenzi C.R., Furlanetto V., Moraes A., 2007. Aplicação de nitrogênio em videiras na Campanha Gaúcha: produtividade e características químicas do mosto da uva. Cienc. Rural, 37, 389-393.

Brunetto G., Ceretta C.A., Melo G.W.B., Kaminski, J., Trentin G., Girotto E., Ferreira P.A.A., Miotto A., Trivelin P.C.O., 2014. Contribution of nitrogen from agricultural residues of rye to 'Niagara Rosada' grape nutrition. Sci. Hort., 169, 66-70.

Brunetto G., Kaminski J., Melo G.W., Brunning F., Mallmann F.J.K., 2006. Destino do nitrogênio em videiras 'Chardonnay' e 'Riesling Renano' quando aplicado no inchamento das gemas. Rev. Bras. Frutic., 28, 497-500.

Calegari A., 2010. Plantas alternativas como cobertura e rotação de culturas. ENPDP, Foz do Iguaçu, Brazil.

Cameron K.C., Di H.J., Moir J.L., 2013. Nitrogen losses from the soil/plant system: a review. Ann. Appl. Biol., 162, 145-173.

Carranca C., Torres M.O., Baeta, J., 2009. White lupine as a beneficial crop in Southern Europe. II. Nitrogen recovery in a legume-oat rotation and a continuous oat-oat. Eur. J. Agro., 31, 190-194.

Carvalho A.M., Amabile R.F., 2006. Cerrado: adubação verde. EMBRAPA, Planaltina, Brazil.

Caviglione J.H., Kiihl L.R.B., Caramori P.H., Oliveira D., 2000. Cartas climáticas do Paraná. IAPAR, Londrina, Brazil.

Chaves J.C.D., 2000. Efeito da adubação mineral, orgânica e verde sobre a fertilidade do solo, nutrição e produção do cafeeiro. In: I Simpósio de Pesquisa dos Cafés do Brasil. v.2, 1389-1392.

Chaves J.C.D., Gorreta R.U., Demoner C.A., Casanova Júnior G., Fantin D., 1997. O amendoim cavalo (Arachis hypogoea) como alternativa para cultivo intercalar em lavoura cafeeira. Londrina: IAPAR, Londrina.

Crews T.E., Peoples M.B., 2005. Can the synchrony of nitrogen supply and crop demand be improved in legume and fertilizerbased agroecosystems? A review. Nutr. Cycl. Agroeco. 72,101-120.

Doneda A., 2010. Plantas de cobertura de solo consorciadas e em cultivo solteiro: Decomposição e fornecimento de nitrogênio ao milho. Dissertação de Mestrado em Ciência do Solo, Universidade Federal de Santa Maria.

Faria C.M.B., Soares J.M., Leão P.C.S., 2004. Adubação verde com leguminosas em videira no submédio São Francisco. R. Bras. Ci. Solo, 28, 641-648.

Ferreira D.F., 2011. Sisvar: a computer statistical analysis system. Cienc. Agrotec., 35, 1039-1042.

Fillery I.R.P., 2001. The fate of biologically fixed nitrogen in legume-based dryland farming systems: a review. Aust. J. Expl. Agric., 41, 361-381.

Fiorin J.E., 1999. Plantas recuperadoras da fertilidade do solo. Curso sobre Fertilidade do solo em Plantio Direto. Ed. Aldeia Norte, Passo Fundo, 39-55.

Fourie J.C, Louw P.J.E., Agenbag G.A., 2006a. Cover crop management in a Chardonnay/99 Richter vineyard in the coastal region, South Africa. 2. Effect of different cover crops and cover crop management practices on grapevine performance. S. Afr. J. Enol. Vitic., 27, 178-186. 
Fourie J.C., Louw P.J.E., Agenbag G.A., 2007. Cover crop management in a Sauvignon Blanc/Ramsey vineyard in the semiArid Olifants River Valley, South Africa. 2. Effect of different cover crops and cover crop management practices on grapevine performance. S. Afr. J. Enol. Vitic., 28, 1114-1123.

Fourie J.C., Louw P.J.E., Calitz F.J., 2006b. Effect of seeding date on the performance of grasses and broadleaf species evaluated for cover crop management in the Breede River Valley wine grape region of South Africa. S. Afr. J. Enol. Vitic., 27, 8-14.

Keller M., Koblet W., 1995. Dry matter and leaf area partitioning, bud fertility and second season growth of Vitis vinifera L.: Responses to nitrogen supply and limiting irradiance. Vitis, 34, 7783.

Keller M., Kummer M., Vasconcelos M.C., 2001. Soil nitrogen utilization for growth and gas exchange by grapevines in response to nitrogen supply and rootstock. Aust. J. Grape Wine R., 7, 2-11.

Ladd J.N., Amato M., Aodes J.M., 1985. Decomposition of plant material in Australian soil. III. Residual organic and microbial biomass $\mathrm{C}$ and $\mathrm{N}$ from isotope-labeled legume material and soil organic matter, decomposing under field condition. Aust. J. Soil Res., 23, 603-611.

Mello L.M.R., 2011. Vitivinicultura brasileira: panorama 2010. Retrieved from: http://www.cnpuv.embrapa.br/publica/artigos/prodvit2010.pdf [accessed in $18^{\text {th }}$ September 2011]

Monteiro A., Lopes C.M., 2007. Influence of cover crop on water use and performance of vineyard in Mediterranean Portugal. Agr. Ecosyst. Environ., 121, 336-342.
Muraoka T., Ambrosano E.J., Zapata F., Bortoletto N., Martins A.L.M., Trivelin P.C.O., Boaretto A.E, Scivittaro W.B., 2002. Eficiencia de abonos verdes (crotalaria y mucuna) y urea, aplicados solos o juntamente, como fuentes de $\mathrm{N}$ para el cultivo de arroz. Terra, 20, 7-23.

Ovalle C., Pozo A., Mark B., Peoples M.B., Lavín A., 2010. Estimating the contribution of nitrogen from legume cover crops to the nitrogen nutrition of grapevines using a ${ }^{15} \mathrm{~N}$ dilution technique. Plant Soil, 334, 247-259.

Pavan M.A., Chaves J.C.D., 1998. A importância da matéria orgânica nos sistemas agrícolas com base nos resultados de pesquisa. 36 p. IAPAR, Londrina (Circular, 98)

Seyr L., 2011. Manejo do solo e ensacamento do cacho em pomar de bananeira 'Nanicão'. Dissertação de Mestrado em Agronomia, Universidade Estadual de Londrina.

Silva E.C., Muraoka T., Espinal F.S.C., Trivelin P.C.O., Buzetti S., 2008. Utilização do nitrogênio da palha de milho e de adubos verdes pela cultura do milho. Rev. Bras. Cienc. Solo, 32, 28532861.

Syvertsen J.P., Smith M.L., 1996. Nitrogen uptake efficiency and leaching losses from lysimeter-grown Citrus trees fertilized at three nitrogen rates. Am. J. Hortic. Sci., 121, 57-62.

Weber M.A., Vinther M., Neergaard A., Amado T.J.C., Lovato T., Acosta J.A.A., Rossato O.B., 2005. Capacidade de fixação simbiótica e liberação de nitrogênio pela ervilhaca (Vicia villosa) medido através de marcação isotópica com ${ }^{15} \mathrm{~N}$. In: $X X X$ Congresso Brasileiro de Ciência do Solo. Sociedade Brasileira de Ciência do Solo. 